\begin{tabular}{l} 
RCCS \\
\hline Annual Review
\end{tabular}

\section{RCCS Annual Review}

A selection from the Portuguese journal Revista Crítica de Ciências Sociais

6 | 2014

Issue no. 6

\title{
The Influence of the Liberal Peace Framework on the United Nations Approach to Peacebuilding in Guinea-Bissau
}

\section{Fernando Cavalcante}

Translator. Sheena Caldwell

\section{Journals}

\section{Electronic version}

URL: http://journals.openedition.org/rccsar/564

DOI: $10.4000 /$ rccsar.564

ISSN: $1647-3175$

Publisher

Centro de Estudos Sociais da Universidade de Coimbra

\section{Electronic reference}

Fernando Cavalcante, «The Influence of the Liberal Peace Framework on the United Nations

Approach to Peacebuilding in Guinea-Bissau », RCCS Annual Review [Online], 6 | 2014, Online since 01 October 2014, connection on 10 December 2020. URL : http://journals.openedition.org/rccsar/564 ;

DOI : https://doi.org/10.4000/rccsar.564 


\section{Fernando Cavalcante}

United Nations Integrated Peacebuilding Office, Guinea-Bissau

\section{The Influence of the Liberal Peace Framework on the United Nations Approach to Peacebuilding in Guinea-Bissau ${ }^{*}$}

The article explores the United Nations approach to peacebuilding in Guinea-Bissau following the 1998-1999 armed conflict in the country. Despite efforts from the United Nations and other international actors, the country seems still far from achieving the sustainable peace advocated by intervenors. The main hypothesis herein sustained is that this limitation is due to the strong basis of the UN approach on the liberal peace framework. This framework is particularly marked by the (usually top-down) promotion of fundamentally liberal values and practices to post-armed conflict situations. It is thus argued that the limitations of the UN approach to peacebuilding are to be found not only in the implementation or operationalization of specific policies, but also in their own design.

Keywords: Guinea-Bissau; United Nations; peace; peacebuilding; conflict resolution.

\section{Introduction}

The United Nations (UN) has been involved in the peacebuilding process in Guinea-Bissau since the late 1990s. Following the armed conflict and the deployment of a peacekeeping operation by the Economic Community of West African States (ECOWAS), the UN established a political office in Bissau to ensure the continuity of the ceasefire. More recently, in addition to transforming this political presence into an "integrated office," the UN included Guinea-Bissau in the agenda of the Peacebuilding Commission (PBC), an intergovernmental advisory body created in 2005 to provide greater coherence and coordination to the efforts of the various actors involved in peacebuilding processes worldwide. ${ }^{1}$

Despite the efforts of the United Nations and other global actors, the situation in GuineaBissau remains fragile and the prospects for improvement seem limited. The years following the 1998-1999 armed conflict have been marked by constant fragility and weakness in the political, institutional and socio-economic structures of the country (Kabia, 2009; Roque,

\footnotetext{
${ }^{*}$ Article published in RCCS 102 (December 2013).

This article is partially based on the author's PhD research, which was funded by a PhD scholarship from the Foundation for Science and Technology (FCT) (reference SFRH/BD/46799/2008) and a Marie Curie fellowship (Initial Training Network) from the European Commission. An earlier version of the text was presented at the International Studies Association (ISA) Annual Convention in 2012, with the support of the University of Coimbra's Faculty of Economics. The author wishes to thank the anonymous RCCS reviewers for their constructive comments on the original version of the text, whilst naturally absolving them of responsibility for any errors or omissions that may remain. The views herein expressed are solely those of the author and do not necessarily represent the official positions of any institution to which he is or has been affiliated.

${ }^{1}$ On the creation of the PBC, see in particular Jenkins (2013), Bellamy (2010) and Neves (2009).
} 
2009; ICG, 2008). Those weaknesses may be illustrated, for example, by the dissolution of parliament by the head of the executive in 2003 and the assassination of former President João Bernardo "Nino" Vieira in 2009. The country continues to have low human development indicators and currently ranks 176 (out of 186 countries) in the latest Human Development Report produced by the United Nations Development Programme (UNDP). Furthermore, other socio-economic indicators usually place the former Portuguese colony below the average for West African countries: approximately $49 \%$ of the population live on less than 1.25 dollars per day (UNDP, 2011), the literacy rate for adults is only $54 \%$ and the gross national income per capita is 1.042 dollars (UNDP, 2013).

Against this backdrop, this article aims to demonstrate that the United Nations approach to peacebuilding in Guinea-Bissau has been particularly limited by its strong adherence to the liberal peace paradigm. This approach, as demonstrated by a now vast line of research, is essentially characterised by the promotion of liberal norms, practices and values, especially those associated with democracy and the market economy (vide, e.g., Richmond, 2005, 2011; Roberts, 2011; Pugh et al., 2008; Duffield, 2007; Paris, 2004). Peacebuilding efforts, when based on the liberal peace tenets, are usually characterised by programmes, practices and actions implemented from the top-down in areas that are not necessarily defined as priorities by local populations or that respond to the root causes of armed conflicts. Consequently, despite occasional progress in some areas (particularly security), peacebuilding processes based on the liberal peace paradigm rarely succeed in creating the necessary conditions for the emergence of a sustainable peace guided by a genuine (rather than virtual) social contract, as would be expected in a liberal democratic society (Richmond, 2011).

The proposed analysis does not intend to examine the causes and consequences of the armed conflict that devastated Guinea-Bissau in the late 1990s, nor assess the impact of UN efforts in the country. On the contrary, this article takes a "step back," focusing on the actual peacebuilding policies and instruments formulated in New York. The basic assumptions underlying the liberal peace are reflected in these policies and instruments, especially in the emphasis they place on the markedly liberal conceptions and worldviews found in their guidelines, priorities and objectives. These conceptions and worldviews necessarily influence the implementation and operationalisation of peacebuilding programmes and projects in the field by UN agencies and other international actors. As such, it is argued that the weakness 
of the UN approach to peacebuilding processes lies not only in the implementation or in the operationalisation of specific policies and projects, but also in their actual conceptualisation and formulation.

The following section outlines the basis for this argument, focusing on the theoreticalpolitical framework of the liberal peace that underpins the United Nations' concept and practices of peacebuilding. The second section then provides an overview of the UN peacebuilding efforts in Guinea-Bissau. It should be noted that this section does not examine the armed conflict in Guinea-Bissau or its consequences exhaustively, but only to the extent necessary to contextualise the UN peacebuilding approach and policies formulated for the country. The third section identifies the extent to which those efforts reflect, albeit implicitly, the principles of the liberal peace paradigm. The final section presents some considerations by way of a conclusion. The analysis is based primarily on the interpretation of official and unofficial primary sources, including internal documents and interviews held with UN and Member State officials who have been directly involved in the dynamics herein analysed.

\section{The United Nations concept and practice of peacebuilding}

According to a recent line of academic research, the UN concept and practice of peacebuilding have been primarily influenced by a sophisticated theoretical-political framework, namely the liberal peace (see, amongst many others, Richmond, 2005, 2011; Chandler, 2010; Pugh et al., 2008; Duffield, 2007; Mac Ginty, 2006; Paris, 2004). According to Oliver Richmond, one of the leading theoreticians in this line of research, the liberal peace presents itself as a "discourse, framework and structure" (Richmond, 2005: 206) that embodies a long, essentially western, tradition of experiences in armed conflicts and thinking about peace. At the core of this framework lies the belief in a simplified version of the "democratic peace" hypothesis, which states that democracies rarely wage war against each other (see Russett, 1993; Doyle, 1983a; 1983b). The "democratic peace" hypothesis should not, however, be confused with the "liberal peace" framework, since the latter, more than a theory about the apparent absence of wars between democracies (i.e. the democratic peace), involves the proactive articulation of the promotion of liberal values and practices in the political, economic, security and social realms as the remedy for the consequences of armed conflicts. The liberal peace thus focuses "not just on domestic political institutions 
and their international implications, but on the character of peace in civil and societal, political, economic, security, and international spheres" (Richmond, 2011: 5).

Theorisations about the influence of the liberal peace on peacebuilding practices stemmed from an academic critique whose objective is to highlight and move beyond the failures and limitations inherently associated with the external, often top-down, promotion of (usually western) systems of democratic governance and free market economies. Richmond (2005: in particular 202-214) underscores the western influence in these efforts when discussing the four strands of thought or discourse about peace that constitute the liberal peace. The first is the victor's peace, a limited and short-lived form of peace essentially associated with the use of military force, normally by hegemonic powers. The next two strands of thought are heavily influenced by the Western European Enlightenment project: the constitutional peace, which reflects the defence, particularly along the lines of the first pacifist movements, of ideas such as cosmopolitism, disarmament, democracy, free trade and humanitarian law; and the institutional peace, based on legal norms and on regulation by international institutions. Finally, the fourth strand of thought or discourse constituting the liberal peace is the civil peace, which is strongly defined by humanitarianism and focuses on social actors and movements (ibidem). The balance between these four strands produces the liberal peace and, at the same time, reflects its aspirations for "freedom and mutual regulation" (Richmond and Franks, 2009: 5).

According to this view, the democratic peace envisaged is assumed as universal and achievable as long as certain "peaceful" methods and techniques are efficiently implemented. The general agreement on the means and techniques, as well as on the purposes and objectives of peacebuilding, would then lead to a "consensus" amongst the main global actors on the idea and practice of peacebuilding. Among the techniques, methods and technologies agreed by those actors, one finds conflict prevention, mediation, peacekeeping and peacemaking, humanitarian aid and conflict resolution (Richmond, 2004). The generalised consensus on these methods thus reflects a discourse and practices that project peacebuilding as the "construction of liberal democracy, with a free market and 
globalized economy, progressive development strategies, and guaranteed human rights" (ibidem: 131-132). ${ }^{2}$

In general, such methods and technologies were developed from various generations of approaches to armed conflict management and 'resolution' (Richmond, 2005: 85-123). In the United Nations, the 1992 Report of the Secretary-General entitled "An Agenda for Peace" is a milestone in this process. In this document, preventive diplomacy, peacemaking, peacekeeping and post-conflict peacebuilding were described as mechanisms or techniques available to UN activities in the field of international peace and security. They were thus defined vis-à-vis a sequential and linear reading of armed conflicts in which preventive diplomacy would be used before the outbreak of direct violence, peacemaking and peacekeeping after the cessation of hostilities, and post-conflict peacebuilding, obviously, after the termination of the armed conflict (A/47/277-S/24111: paragraph 20-21).

Produced in the period immediately after the end of the Cold War and the dissolution of the Soviet Union, the document brought the strong influence of the liberal peace to bear on the concept of peacebuilding. In fact, the author of the report explicitly assumed a direct and unequivocal relationship between the promotion of democracies and peace, stating that "[t]here is an obvious connection between democratic practices - such as the rule of law and transparency in decision-making - and the achievement of true peace and security in any new and stable political order" (A/47/277-S/24111: paragraph 59). Other aspects of the liberal peace, especially those associated with its external, top-down promotion, may be found in other UN documents, including the most recent "conceptual basis" produced by the Policy Committee of the Secretary-General ${ }^{3}$ in 2007 . The basis, which should, in theory, be adopted throughout the UN system, reflects this conception, although in a subtle and complex manner:

Peacebuilding involves a range of measures targeted to reduce the risk of lapsing or relapsing into conflict by strengthening national capacities at all levels for conflict management, and to lay the foundations for sustainable peace and development. Peacebuilding strategies must be coherent and tailored to the specific needs of the country concerned, based on national ownership, and should comprise a carefully prioritized, sequenced, and therefore relatively narrow set of activities aimed at achieving the above objectives. (United Nations, 2007: 1)

\footnotetext{
2 Despite the different conceptions of "democracy," it is important to stress that in the UN context visions of "democracy" have always been associated with the western liberal tradition. For an in-depth analysis, see Haack (2011).

${ }^{3}$ The Committee is the highest decision-making body within the Secretariat. It is chaired by the SecretaryGeneral and composed of the heads of some of the most influential UN organizational structures.
} 
The influence of liberal peace, however, is not restricted to conceptual formulations. On the contrary, in activities effectively undertaken in conflict or post-armed conflict contexts since the end of the Cold War, the main global actors gradually began to operate in accordance with a shared horizon for the promotion of liberal values and practices. In fact, in spite of the differences identified among the several peacebuilding initiatives carried out by the UN since the 1990s, its peace operations have normally promoted "free and fair elections, the construction of democratic political institutions, respect for civil liberties, and market-oriented economic reforms" (Paris, 1997: 63).

Concretely, peacebuilding efforts based on the liberal peace project have implied the following, amongst other measures: provision of technical assistance to national governments with a view to, for example, identifying specific needs and priorities; support to the promotion of democratic values and practices and human rights; direct or indirect support to processes of security sector reform; and support to national reconciliation processes and poverty reduction initiatives. ${ }^{4}$ Many of these tasks gradually began to be carried out as part of UN peacekeeping operations from the late 1980s onwards, although they were not usually classified or defined under the heading of peacebuilding at the time. However, at the core of these activities, there was always the underlying idea that "certain kinds of (liberally constituted) societies will tend to be more peaceful, both in their domestic affairs and in their international relations, than illiberal states are" (Newman et al., 2009: 11).

Conceived along these lines, the liberal peace is understood as a top-down approach that too often ignores or neglects the everyday needs and socio-economic realities found in the specific contexts of armed conflicts. Consequently, although sometimes succeeding in obtaining results such as a short-term reduction of violence, interventions guided by the liberal peace paradigm frequently fail to provide the conditions required to achieve sustainable peace, usually discouraging the emergence of a genuine social contract between the population at hand and the state which represents them (Richmond, 2011: 4-13).

\footnotetext{
${ }^{4}$ For examples and in-depth discussion of how these tasks have been carried out in specific contexts, see Paris and Sisk (2009), Newman et al. (2009), Berdal and Economides (2007) and Durch (2006), amongst others.
} 


\section{The United Nations approach to peacebuilding in Guinea-Bissau}

Although this section does not intend to provide an exhaustive analysis of the subject, it should be stressed that the armed conflict initiated in June 1998 in Guinea-Bissau was the consequence of a complex web of internal, regional and international factors. Among the structural causes of the conflict, one finds the Portuguese colonial legacy, which left profound marks on the economic, social and political structures, as well as on the infrastructure of the country. Secondly, the war of independence (1963-1974) left a surplus of weapons in the country that was later used by individuals in the armed forces and in the government to illegally supply separatist armed groups in Senegal. Finally, in the postindependence period, the long-lasting rule of the African Party for the Independence of Guinea and Cape Verde (PAIGC) contributed significantly to consolidate an autocratic and corrupt state apparatus strongly personified in the figure of João Bernardo "Nino" Vieira, who remained in power between 1980 and 1998. This tangled web of factors, intertwined with the political and diplomatic interests of the former colonial powers in the region (Portugal, France and the Netherlands), created the general context for the armed conflict of 1998-1999 and would influence the work of the UN in Guinea-Bissau in the post-conflict period. ${ }^{5}$

According to Adebajo (2002: 111), the immediate causes of the armed conflict in 1998 lay in the deteriorating relations between Nino Vieira and the head of the Armed Forces, General Ansumane Mane. Both accused each other of involvement with the Casamance separatist movement in Senegal, and of responsibilities in the smuggling of arms to this country. Upon Vieira's decision to replace Mane as head of the Armed Forces, the latter initiated a military campaign that eventually led to the establishment of a military junta following the fall of Nino Vieira (who had also come to power via a coup d'état) in May 1999. Between the replacement of Mane and the downfall of Nino Vieira, the armed confrontation in the country caused hundreds of deaths and a large number of internally displaced persons and refugees in neighbouring countries (ibidem: 126), in addition to bringing the national economy to a virtual standstill (Rudebeck, 2001: 12).

\footnotetext{
${ }^{5}$ For a more detailed exploration of the causes of the conflict, see ICG (2008), Ferreira (2004), MacQueen (2003), Forrest (2002), Adebajo (2002: 111-136), Rudebeck (2001) and Ostheimer (2001). On the responses of other international actors to the conflict, in particular the ECOWAS and the Portuguese-speaking countries, see the previously cited works by MacQueen and Adebajo, as well as Kabia (2009: 137-142), Obi (2009) and Roque (2009). On the more recent involvement of the European Union, see Gibert (2009).
} 
The first multilateral responses to the armed conflict came from the ECOWAS and the Community of Portuguese-Speaking Countries (CPLP), who succeeded in brokering a peace agreement between Nino Vieira and Mane, which was signed in Abuja (Nigeria) in August 1998. Under the terms of the agreement, Nino Vieira and Mane reaffirmed the ceasefire arranged a few days before and agreed to the complete withdrawal of all foreign military forces from the country, as well as to hold general and presidential elections by March 1999 (S/1998/1028). The agreement also envisaged the deployment of an ECOWAS interposition force, supplied by its Monitoring Group (the ECOMOG, Economic Community of West African States Monitoring Group). It should be emphasised that this force was not led by the UN, but by a sub-regional organisation, and that it would only later be endorsed by the UN Security Council (S/RES/1216). In Adebajo's assessment, the result of the ECOMOG efforts would prove to be limited due to its premature withdrawal after ECOWAS observed a significant deterioration in the security situation, as well as to the logistic and financial difficulties faced by the Group (Adebajo, 2002: 119-124).

The United Nations only began to play a more significant role in the peace process after the signing of the Abuja agreement. Through staff at the Department of Political Affairs (DPA), the UN became involved in political initiatives in Bissau with the aim of ensuring and maintaining the ceasefire and guaranteeing the consolidation of the "fragile peace" that had begun to emerge in the country. ${ }^{6}$ One of such initiatives was the establishment of the United Nations Peacebuilding Office in Guinea-Bissau (UNOGBIS), in March 1999. ${ }^{7}$ This model of political presence replicated the format of the United Nations Office in Liberia (UNOL), established in 1997 as part of the exit strategy of ECOMOG and of a UN observer mission in this country (DPA and UNDP, 2001: 9). The primary function of UNOGBIS, according to its original mandate, was to help create an "an enabling environment for restoring and consolidating peace, democracy and the rule of law and for the organization of free and transparent elections," in addition to facilitating implementation of the Abuja agreement (S/1999/232: 1). In New York, the presence of allied countries in the Security Council

\footnotetext{
${ }^{6}$ Interview with senior official of the UN Department of Political Affairs, New York, 16.11.2010.

${ }^{7}$ Not to be confused with the Peacebuilding Support Office (PBSO). Offices such as UNOGBIS are established in the field, usually have a mandate defined by the Security Council and normally operate under the aegis of the DPA. The PBSO, a New York-based Secretariat organ, was established in 2006 and is governed by its own terms of reference.
} 
(namely France, Gambia and Portugal) ensured the continued interest of this body and of the UN in Guinea-Bissau (Adebajo, 2002: 119).

Notwithstanding the unstable environment and the fragility of the actual agreement mediated by the ECOWAS, which became evident after the fall of Nino Vieira in May, the role of the UN in providing support for the holding of parliamentary and presidential elections was of great importance. Through the United Nations Development Programme (UNDP), the UN provided technical support for the national authorities during "various stages" of the electoral process, including, for instance, the preparation of the operational plan for training election officials (ibidem: 127-128). United Nations documents reveal that the UNDP supported the registration of over half a million voters, in addition to having initiated "a massive civic education campaign to inform and educate the electorate on the electoral process" (S/1999/1276: paragraph. 16). UNOGBIS, in turn, organised election debates amongst the candidates and coordinated the election observation efforts (ibidem: par. 17-19). Subsequent reports from the Secretary-General on developments in GuineaBissau and the work of UNOGBIS point out the active role of the United Nations in various areas during the period following the elections. UNOGBIS, for instance, offered its good offices in negotiations aimed at redefining the future role of the military in the democratic period (S/2000/250: par. 7), and carried out specific activities in what concerns the training of legislative and judiciary staff (S/2001/622: par. 24).

In addition to its presence and efforts in the field, mainly via UNOGBIS, concerted diplomatic efforts towards peacebuilding in Guinea-Bissau were carried out in New York from 2002 onwards. These efforts intensified following the creation of the so-called Ad Hoc Advisory Group for Guinea-Bissau, established under the aegis of the Economic and Social Council (ECOSOC). This group, which had a similar structure and functions to the one previously established for Haiti, was created in the context of broader institutional initiatives aimed at strengthening the links between peace and security and development issues in UN peacebuilding efforts (Prantl, 2006). In fact, despite some existing awareness of the interrelationship between peace and security and development, ${ }^{8}$ responsibilities over those

\footnotetext{
${ }^{8}$ On the relationship between peace, security and development, see in particular Mac Ginty and Williams (2009), Tschirgi et al. (2010) and Collier et al. (2003). At the time the ad hoc groups were active, Collier and his team estimated that at the end of a civil war the "typical country" had a $44 \%$ chance of returning to a situation of armed conflict within five years (Collier et al. 2003: 83). Despite future revisions and harsh methodological
} 
issues remained, from an institutional perspective, clearly divided between the Security Council and the ECOSOC, respectively (ibidem: 9).

The Guinea-Bissau Group was composed of five Permanent Representatives from Member States of the United Nations (South Africa, Brazil, the Netherlands and Portugal, in addition to Guinea-Bissau itself), and sought to "examine [the country's] humanitarian and economic needs, and review relevant programmes of support and prepare recommendations for a long-term programme of support," as well as to "provide advice on how to ensure that the assistance of the international community was adequate, coherent, well coordinated and effective and promoted synergy" (Decision 2002/304, cited in Prantl, 2006: 151). According to a diplomat with responsibilities related to the Group at the time, by supporting long-term activities outside the strict area of security, the diplomatic efforts undertaken within the ECOSOC sought precisely to bring the development sphere closer to the dimensions of peace, security and stability. ${ }^{9}$ In practice, the Group's work was meant to serve as a platform for coordinating the efforts undertaken in the country by agencies and programmes within the UN system. A set of short- and long-term recommendations was therefore drawn up with the aim of interconnecting the peacebuilding efforts of the various entities within the UN system working in Guinea-Bissau. ${ }^{10}$ It should be noted, however, that the recommendations of the Group, due to its very nature, were not binding.

According to Prantl (2006), who conducted an external assessment commissioned by the ECOSOC, the most important function of the Council's ad hoc groups was to lobby in favour of countries that normally have no easy access to the frontline of international financial aid. The Guinea-Bissau Group thus aimed to serve as a link between national authorities and international partners. In this sense, whilst the government "would actively promote policy goals such as the implementation of the rule of law and political stability, international donors would provide the funding for emergency support and technical assistance in a wide range of fields" (Prantl, 2006: 14).

criticisms, this estimate gained widespread acceptance amongst political decision-makers in New York, and was rhetorically used as a justification for the creation of the PBC in 2005, as Suhrke and Samset argue (2007).

${ }^{9}$ Interview with senior diplomat from a Member State of the PBC Specific Configuration for Guineau-Bissau, New York, 17.12. 2010.

${ }^{10}$ Documents relating to the Ad Hoc Advisory Group for Guinea-Bissau, including recommendations and activity reports, are available at https://www.un.org/en/ecosoc/adhocmech/bissau.shtml (last consulted on 05.02.2013). 
The ECOSOC terminated the mandate of its Ad Hoc Group for Guinea-Bissau in July 2008, following the inclusion of the country in the agenda of the then recently established Peacebuilding Commission (E/RES/2008/30). In December 2007, the Security Council had submitted to the Commission a request for advice on the situation in the country in the following areas: government capacity in the areas of finance, security sector reform and anticorruption measures; previous measures aimed at developing and strengthening the security system, the judiciary and the rule of law; the development of democratic practices and preparations for the holding of elections in the following year (S/2007/744). Following the PBC's acceptance of the request, the Commission's so-called Specific Configuration for Guinea-Bissau would became the main intergovernmental locus for the discussion of issues related to peacebuilding efforts in the country.

Within the context of the Configuration, the most concrete peacebuilding efforts took the form of the Strategic Framework for Peacebuilding in Guinea-Bissau, adopted in October 2008 (PBC/3/GNB/3). The document was produced on the basis of a consultation process involving members of the CSC-Guinea-Bissau, UN staff and Bissau-Guinean authorities during several months. ${ }^{11}$ These efforts included, for example, a joint visit from the Chair of the CSCGuinea-Bissau and UN staff to the country in January 2008 (PBC/2/GNB/6), as well as visits from CSC delegations in April and June of the same year. In New York, informal thematic sessions took place with the aim of discussing issues that were potentially a priority for peacebuilding in the country (e.g. drug trafficking). Finally, the Secretariat drew up a map of existing resources and main gaps for peacebuilding in Guinea-Bissau (PBC/2/GNB/7).

In addition to diplomatic coordination efforts undertaken within the framework of the Commission, the Peacebuilding Fund (PBF) was used to support the implementation of small projects with potential catalytic effect on peacebuilding in the country. Financial support from the Fund was initially planned in two stages. The first phase had a political purpose and was essentially destined to demonstrate support for the peacebuilding process in the country. It was expected that the implementation of projects in this phase would also serve to identify opportunities for greater PBF support in the future. ${ }^{12}$ In this context, the Fund allocated six million dollars to Guinea-Bissau in April 2008. According to a member of the

\footnotetext{
${ }^{11}$ Interview with member of the Peacebuilding Support Office staff, New York, 15.11.2010.

12 Interview with senior diplomat from a Member State of the PBC Specific Configuration for Guinea-Bissau, New York, 17.12.2010.
} 
PBSO staff at the time, this sum reflected the assessment that the country lacked the capacity to absorb a higher amount. ${ }^{13}$ The second 'envelope', according to UN jargon, was only approved in January 2011 due to a series of delays in drawing up the priority plan for Guinea-Bissau. The sum total of this last envelope was 16.8 million dollars. ${ }^{14}$

The PBF net financial contribution to peacebuilding projects in Guinea-Bissau up to December 2012 was approximately 23.8 million dollars. ${ }^{15}$ To put this figure into context, it should be emphasised that the estimate for resources required to ensure the functioning of UNIOGBIS (the revised version of the UNOGBIS; see below), was 19.9 million dollars for the year 2013 alone (A/67/346/Add.3: Table 1). It should also be noted that the PBF amount destined for Guinea-Bissau is the lowest of all the countries currently on the PBC agenda, representing only $7 \%$ of the net total disbursed by the Fund ( 339.4 million USD) since it was launched in October $2006 .{ }^{16}$ In short, although at first sight the total value of the PBF financial contribution to Guinea-Bissau may appear significant, it is less so when viewed from a broader perspective.

More recently, with a view to incorporating systemic guidelines to foster greater integration and coherence in the activities undertaken by entities within the UN system, UNOGBIS was converted into the United Nations Integrated Peacebuilding Office in GuineaBissau (UNIOGBIS). As the focal point for UN activities in the country, the new Office has wider and more inclusive duties. More specifically, the primary function of the new Office is to assist the PBC in its activities towards Guinea-Bissau, in addition to providing support to the national government in various areas, including security sector reform and the strengthening of rule of law institutions (S/RES/1876:paragraph. 3).

In short, since the conflict that devastated the country in 1998-1999, the United Nations approach to peacebuilding in Guinea-Bissau has primarily focused on political and diplomatic initiatives involving relevant actors in New York and Bissau, principally via diplomatic forums and political offices in the field.

\footnotetext{
${ }^{13}$ Interview with former member of the Peacebuilding Support Office staff, via videoconferencing, 18.06.2012.

${ }^{14}$ Interview with senior diplomat from a Member State of the PBC Specific Configuration for Guinea-Bissau, New York, 17.12.2010.

${ }^{15}$ Unless otherwise stated, all figures referring to the PBF discussed in this article are presented as current USD values and were compiled by the author from data available on the UNDP Multi-Partner Trust Fund Office website (http://mptf.undp.org/). The data reflects current values as of 29.12.2012.

${ }^{16}$ Compiled by the author from data available on the MPTF-UNDP website. See note 15.
} 
The results of these efforts, however, have been limited. The elections held after the armed conflict were marked by serious endemic problems, including the inexperience of the opposition parties and the deterioration of the capacities and integrity of civil servants (Ostheimer, 2001: 47). The military continued to act as a kind of parallel power in the country, with Mane's influence on the executive extending to the point of "banning" a state visit by the Bissau-Guinean President to Senegal (ibidem: 48). In the months and years which followed, the President's failure to promulgate the new constitution and the eventual dissolution of parliament would lead to a new coup d'état carried out by the military in September 2003 (IRIN, 2003). From a socio-economic point of view, the country's GDP per capita, measured at purchasing power parity, fell from 1,070 dollars in 1997, before the civil war, to 710 dollars in 2002 (UNDP, 2004: 187). These limitations, however, stemmed not only from problems related to the implementation and operationalization of specific policies, but also from the theoretical-political framework of the liberal peace that underlies the UN peacebuilding efforts in the country.

\section{Echoes of the liberal peace}

The influence of the liberal peace theoretical-political framework may be found in different aspects and at different levels of the UN peacebuilding efforts in Guinea-Bissau. In fact, an analysis of the overall lines of the UN approach to peacebuilding in the country after the 1998 armed conflict reveals a strong emphasis on the promotion of values, norms and practices that reflect the projection of liberal states, particularly in what concerns their model of political (democracy) and socio-economic governance (market economies) (vide Newman et al., 2009: 11).

The influence of liberal peace may be identified in different bodies. The mandates of the organs and entities appointed to deal with peacebuilding in Guinea-Bissau, for example, do not fail to make clear connections between the importance ascribed to activities associated with promoting democracy and achieving peace, thus reflecting one of the key ideas of the liberal peace paradigm. The mandates of UNOGBIS, and later of UNIOGBIS, explicitly reflect this formulation, given that they refer to the need to create "an enabling environment for restoring and consolidating peace, democracy and the rule of law and for the organization of free and transparent elections" (S/1999/232, 1), or assume the need to strengthen "the 
capacities of national institutions in order to maintain constitutional order, public security and the full respect for the rule of law" (S/RES/1876, par. 3b).

The mandate of the ECOSOC Advisory Group also refers to aspects of the liberal peace, particularly with regard to the link between market economies and the attainment of peace. In its Resolution 2005/2, for instance, the Group expressly recognises that the main challenges faced by Guinea-Bissau were to "restore fiscal discipline [...] and improve the climate for private investment and economic diversification" (E/RES/2005/2). In this passage, the connection between "fiscal discipline" and "climate for private investment" as challenges for the peacebuilding process in the country further reinforces the central premise that market democracies are a "remedy" for the consequences of armed conflict, in line with formulations based on theorisations about the liberal peace.

More recently, the efforts of the PBC CSC-Guinea-Bissau do not seem disconnected from the basic premises of the liberal peace. Its main instrument, the Strategic Framework for Peacebuilding in Guinea-Bissau, identifies six priority areas: elections; measures to jumpstart the economy and rehabilitate infrastructure; security and defence sector reform; strengthening of the justice sector, consolidation of the rule of law and the fight against drug trafficking; the reform and modernisation of the public administration; and social issues relating to peacebuilding $(\mathrm{PBC} / 3 / \mathrm{GNB} / 3,14-17)$. As previously mentioned, these areas reveal aspects of primary concern for the liberal peace paradigm, such as security sector reform and the rule of law.

The existence of premises fundamental to the liberal peace framework within the mandates of UN bodies, as well as in their peacebuilding instruments and policies, is of crucial importance, since they are the entities that define the guidelines, priorities and objectives of the UN approach towards countries such as Guinea-Bissau. Consequently, the implementation and/or operationalisation of UN policies and projects in this area are necessarily shaped in light of the liberal peace framework. It is this framework that defines, for instance, the areas that may or may not be contemplated in specific actions, as well as those which will receive priority support.

It is important to highlight that the policies and instruments guiding UN involvement are usually formulated with significant technical support from the Secretariat or traditional donors, frequently without the effective involvement of interlocutors representing the Bissau-Guinean society, which also illustrates a channel for the transmission of values and 
practices associated with the liberal peace from the so-called 'international community' to countries such as Guinea-Bissau (Paris, 2002: 644). As discussed in the previous section, this transmission occurred not only during the drafting of the Strategic Framework, but also during the implementation of other efforts in the field, such as the holding of elections or the drafting of programmes aimed at restoring fiscal discipline in the country. Taken as a whole, such efforts may be seen as an attempt by the Commission to assume a significant role in defining and identifying peacebuilding priorities for the country.

The impact of the liberal peace that underlies the United Nations peacebuilding practice becomes even clearer when the overall characteristics of PBF disbursements to GuineaBissau are considered. The projects supported by the Fund in Guinea-Bissau may be divided into four thematic areas, in accordance with the PBF Terms of Reference (A/63/818: 5). ${ }^{17}$ The majority of the projects (five) were classified under the heading of support to the implementation of peace agreements and political dialogue, with four of them having projected impacts on security sector reform in particular (see Table 1). As a whole, the four projects represent half (12 million dollars) of the total net amount transferred by the Fund to projects in Guinea-Bissau up to December 2012. These projects sought, amongst other objectives, to improve working conditions in military installations and hold a national conference on the defence and security sectors. On the other hand, one single project, budgeted at one million dollars, prioritised the promotion of sustainable livelihoods in Guinea-Bissau. Specifically, this project aimed to improve Bissau-Guinean women's economic rights. Despite the significant amount, it should be noted that the project was approved within the context of the Immediate Response Facility (IRF), a PBF financing mechanism that supports projects, not programmes (see A/63/818: 6); in other words, this specific project was not necessarily drawn up in accordance with the long-term plans envisaged in the Strategic Framework outlined by the PBC. ${ }^{18}$

\footnotetext{
${ }^{17}$ Interview with staff member of the Peacebuilding Support Office, 09.10.2012.

${ }^{18}$ All data compiled from information available on the MPTF-UNDP website (http://mptf.undp.org/).
} 
Table 1: Distribution of PBF funding in Guinea-Bissau

\begin{tabular}{|c|c|c|c|c|}
\hline \multirow{2}{*}{ Thematic areas, with subcategories } & \multicolumn{2}{|c|}{ Projects } & \multicolumn{2}{|c|}{$\begin{array}{l}\text { Net } \\
\text { Transfers }\end{array}$} \\
\hline & Quant. & $\%$ & $\begin{array}{l}\text { Millions } \\
\text { of USD }\end{array}$ & $\%$ \\
\hline $\begin{array}{l}\text { 1. Support for the implementation of peace agreements and } \\
\text { political dialogue }\end{array}$ & 5 & 42 & 12.9 & 54 \\
\hline 1.1. Security sector Reform (SSR) & 4 & 33 & 12 & 50 \\
\hline 1.2. Rule of law & 1 & 9 & 0.9 & 4 \\
\hline 1.3. Disarmament, demobilisation and reintegration & - & - & - & - \\
\hline 1.4. Enhancing political dialogue for peace agreements & - & - & - & - \\
\hline 2. Promotion of coexistence and peaceful resolution of conflict & 2 & 16 & 2.4 & 10 \\
\hline 2.1. National reconciliation & 1 & 8 & 1.4 & 6 \\
\hline 2.2. Democratic governance & 1 & 8 & 1 & 4 \\
\hline 2.3. Management of natural resources & - & - & - & - \\
\hline $\begin{array}{l}\text { 3. Economic revitalisation and generation of immediate peace } \\
\text { dividends }\end{array}$ & 3 & 25 & 7.5 & 32 \\
\hline 3.1. Creating short-term job opportunities & 2 & 17 & 6.5 & 28 \\
\hline 3.2. Sustainable livelihoods & 1 & 8 & 1 & 4 \\
\hline $\begin{array}{l}\text { 4. (Re)establishing essential administrative services and related } \\
\text { human and technical capacities }\end{array}$ & 2 & 17 & 1 & 4 \\
\hline 4.1. Public administration & 2 & 17 & 1 & 4 \\
\hline 4.2. Provision of public services (including infrastructures) & - & - & - & - \\
\hline TOTAL & 12 & 100 & 23.8 & 100 \\
\hline
\end{tabular}

Source: Data available on the MPTF Office website (http://mptf.undp.org/). The thematic areas reflect the Fund's Terms of Reference $(A / 63 / 818)$ and the subcategories are in accordance with those used internally in the PBSO (information obtained from interviews with the Office staff).

Significant echoes of the liberal peace paradigm can thus be detected in United Nations peacebuilding efforts in Guinea-Bissau. Although often implicit, these echoes may be identified in the mandates of organs and entities with specific responsibilities in the area of peacebuilding in the UN, where priorities and objectives are defined in the first place. Consequently, those echoes are also present in the implementation and format of programmes and projects carried out by the UN and other international actors in the field.

\section{Final considerations}

In spite of the involvement of the United Nations and the so-called "international community" following the 1998-1999 armed conflict, Guinea-Bissau does not appear to have achieved the sustainable peace desired by those actors. In fact, the country's socioeconomic development indicators remain very low, with some still at similar levels to 1997, prior to the outbreak of the civil war. Furthermore, political events such as failed coups d'états in the early 2000s, the assassination of former President Nino Vieira in 2009 and the 
recent military incursions into the political life of the country in April 2012 indicate that important political and institutional challenges still persist in Guinea-Bissau. In this sense, the situation in the country demonstrates the fragility and the limitations of the liberal peace paradigm that underlies the UN approach to peacebuilding in post-armed conflict situations.

This article demonstrated that the United Nations approach to the peacebuilding process in Guinea-Bissau since the late 1990s has been heavily based on the theoretical-political framework of the liberal peace. It has identified the influence of this approach not only in the implementation phase of UN projects and activities in the field, but also during their design. The article argued that the limitations of UN peacebuilding are related not only to the implementation of specific policies, but also to their actual preparation and design, since the definition of guidelines, priorities and objectives already incorporates conceptions and worldviews that are subsequently transmitted vertically, from the top-down, in post-armed conflict situations. In this sense, any analysis of these processes needs to consider not only the implementation of concrete actions in the field, but also their implicit values.

The analysis undertaken here not only confirms that the UN peacebuilding concept and practice in Guinea-Bissau have been influenced by the liberal peace, but also points to the persistence of this theoretical-political framework as the paradigm underlying the UN approach to the former Portuguese colony over the past fifteen years. In effect, despite some changes and innovations in UN efforts (e.g. the creation and redefinition of political offices in the field and institutional reforms in New York), the general approach to peacebuilding in the country is still excessively based on the promotion of markedly liberal values and practices, particularly through diplomatic support, the definition of priorities and support to areas deemed relevant for the construction of a liberal state that resembles the political systems in the Global North. In this sense, future reviews and approaches to UN peacebuilding in Guinea-Bissau must also include more in-depth considerations that examine the compatibility and relevance of the liberal peace framework in that specific context.

Translated by Sheena Caldwell

Revised by the author and Teresa Tavares 


\section{References}

Adebajo, Adekeye (2002), Building Peace in West Africa: Liberia, Sierra Leone and Guinea-Bissau. Boulder: Lynne Rienner.

Bellamy, Alex J. (2010), "The Institutionalisation of Peacebuilding: What Role for the UN Peacebuilding Commission?" in Oliver P. Richmond (ed.), Peacebuilding: Critical Developments and Approaches. Basingstoke: Palgrave Macmillan, 193-210.

Berdal, Mats; Economides, Spyros (eds.) (2007), United Nations Interventionism, 1991-2004. Cambridge: Cambridge University Press.

Chandler, David (2010), International Statebuilding: The Rise of Post-Liberal Governance. London: Routledge.

Collier, Paul; Elliot, V.L.; Hegre, Håvard; Hoeffler, Anke; Reynal-Querol, Marta; Sambanis, Nicholas (2003), Breaking the Conflict Trap: Civil War and Development Policy. Washington, DC: The World Bank/Oxford University Press.

Doyle, Michael W. (1983a), "Kant, Liberal Legacies, and Foreign Affairs," Philosophy and Public Affairs, 12(3): 205-235.

Doyle, Michael W. (1983b), "Kant, Liberal Legacies, and Foreign Affairs, Part 2," Philosophy and Public Affairs, 12(4): 323-353.

DPA \& UNDP (2001), "Report on UN Post-Conflict Peace-Building Support Offices," Internal document, July (34 pp.). New York: Department of Political Affairs/United Nations Development Programme.

Duffield, Mark (2007), Development, Security and Unending War: Governing the World of Peoples. Cambridge: Polity Press.

Durch, William J. (ed.) (2006), Twenty-First-Century Peace Operations. Washington, DC: United States Institute of Peace, The Henry L. Stimson Center.

Ferreira, Patrícia M. (2004), "Guinea-Bissau: Between conflict and democracy," African Security Review, 13(4): 45-56.

Forrest, Joshua (2002), "Guinea-Bissau," in Patrick Chabal (ed.), A History of Postcolonial Lusophone Africa. Bloomington: Indiana University Press, 236-263.

Gibert, Marie V. (2009), "The Securitisation of the EU's Development Agenda in Africa: Insights from Guinea-Bissau," Perspectives on European Politics and Society, 10(4): 621-637.

Haack, Kirsten (2011), The United Nations Democracy Agenda: A Conceptual History. Manchester: Manchester University Press.

ICG (2008), "Guinea-Bissau: In Need of a State," Africa Report, 142, 2 July. Brussels/Dakar: International Crisis Group. Last accessed on 06.02.2013, at http://www.crisisgroup.org/ /media/Files/africa/west-africa/guinea-bissau/GuineaBissau\%20In\%20Need\%20of\%20a\%20State.pdf.

IRIN (2003), Guinea-Bissau: Army Ousts President Who Kept Delaying Elections. 14 September. Integrated Regional Information Networks. Last accessed on 05.02.2013, at http://www.irinnews.org/Report/46145/GUINEA-BISSAU-Army-ousts-president-who-keptdelaying-elections.

Jenkins, Rob (2013), Peacebuilding: From Concept to Commission. New York: Routledge.

Kabia, John M. (2009), Humanitarian Intervention and Conflict Resolution in West Africa: From ECOMOG to ECOMIL. Farnham: Ashgate. 
Mac Ginty, Roger (2006), No War, no Peace: The Rejuvenation of Stalled Peace Processes and Peace Accords. Basingstoke: Palgrave Macmillan.

Mac Ginty, Roger; Williams, Andrew (2009), Conflict and Development. Abingdon, UK: Routlegde.

MacQueen, Norrie (2003), "A Community of Illusions? Portugal, the CPLP and Peacemaking in Guinea-Bissau," International Peacekeeping, 10(2): 1-26.

Neves, Gilda Motta Santos (2009), Comissão Nações Unidas para Consolidação da Paz: Perspectiva Brasileira. Brasília: FUNAG.

Newman, Edward; Paris, Roland; Richmond, Oliver P. (eds.) (2009), New Perspectives on Liberal Peacebuilding. Tokyo: United Nations University Press.

Obi, Cyril I. (2009), "Economic Community of West African States on the Ground: Comparing Peacekeeping in Liberia, Sierra Leone, Guinea-Bissau and Côte d'Ivoire," African Security, 2(2-3): 119-135.

Ostheimer, Andrea E (2001), "The Structural Crisis in Guinea-Bissau's Political System," African Security Review, 10(4): 45-57.

Paris, Roland (1997), "Peacebuilding and the Limits of Liberal Internationalism," International Security, 22(2): 54-89.

Paris, Roland (2002), "International Peacebuilding and the 'Mission Civilisatrice'," Review of International Studies, 28(4): 637-656.

Paris, Roland (2004), At War's End: Building Peace after Civil Conflict. New York: Cambridge University Press.

Paris, Roland; Sisk, Timothy D. (eds.) (2009), The Dilemmas of Statebuilding: Confronting the Contradictions of Postwar Peace Operations. Abingdon, UK: Routledge.

Prantl, Jochen (2006), "ECOSOC Ad Hoc Advisory Groups on African Countries Emerging from Conflict: The Silent Avant-Garde." New York: Department of Economic and Social Affairs, Office for ECOSOC Support and Coordination.

Pugh, Michael; Cooper, Neil; Turner, Mandy (eds.) (2008), Whose Peace? Critical Perspectives on the Political Economy of Peacebuilding. London: Palgrave.

Richmond, Oliver P. (2004), "The Globalization of Responses to Conflict and the Peacebuilding Consensus," Cooperation and Conflict, 39(2): 129-150.

Richmond, Oliver P. (2005), The Transformation of Peace. Basingstoke: Palgrave Macmillan.

Richmond, Oliver P. (2011), A Post-Liberal Peace. London: Routledge.

Richmond, Oliver P.; Franks, Jason (2009), Liberal Peace Transitions: Between Statebuilding and Peacebuilding. Edinburgh: Edinburgh University Press.

Roberts, David (2011), Liberal Peacebuilding and Global Governance: Beyond the Metropolis. London: Routledge.

Roque, Sílvia (2009), "Peacebuilding in Guinea-Bissau: A Critical Approach." Noref Report 7, May. 21pp. Oslo: Norwegian Peacebuilding Centre (Noref).

Rudebeck, Lars (2001), Colapso e reconstrução política na Guiné-Bissau, 1998-2000: Um estudo de democratização difícil. Uppsala: The Nordic Africa Institute.

Russett, Bruce M. (1993), Grasping the Democratic Peace: Principles for a Post-Cold War World. Princeton: Princeton University Press. 
Suhrke, Astri; Samset, Ingrid (2007), "What's in a Figure? Estimating Recurrence of Civil War," International Peacekeeping, 14(2): 195-203.

Tschirgi, Neclâ; Lund, Michael S.; Mancini, Francesco (eds.) (2010), Security and Development: Searching for Critical Connections. Boulder: Lynne Rienner.

United Nations (2007), "Decision No. 2007/28 - Peacebuilding Support Office," Internal document, 22 May (4 pp.). New York: Policy Committee, United Nations.

UNDP (2004), Human Development Report: Cultural Liberty in Today's Diverse World. New York: United Nations Development Programme.

UNDP (2011), Human Development Report: Sustainability and Equity: A Better Future for All. New York: United Nations Development Programme.

UNDP (2013), Human Development Report: The Rise of the South: Human Progress in a Diverse World. New York: United Nations Development Programme.

\section{Official United Nations documents}

A/47/277-S/24111, "An Agenda for Peace: Preventive Diplomacy, Peacemaking and Peace-keeping" [Report of the Secretary-General pursuant to the statement adopted by the Summit Meeting of the Security Council on 31 January 1992], 17.06.1992.

A/63/818, Arrangements for the Revision of the Terms of Reference for the Peacebuilding Fund [Report of the Secretary-General], 13.04.2009.

A/67/346/Add.3, Estimates in Respect of Special Political Missions, Good Offices and Other Political Initiatives Authorized by the General Assembly and/or the Security Council - Thematic Cluster III: United Nations Offices, Peacebuilding Support Offices, Integrated Offices and Commissions [Report of the Secretary-General], 15.10.2012.

E/RES/2005/2, Resolution 2005/2 [Ad Hoc Advisory Group on Guinea-Bissau], 01.03.2005.

E/RES/2008/30, Resolution 2008/30 [Ad Hoc Advisory Group on Guinea-Bissau], 25.07.2008.

PBC/2/GNB/6, Report of the Mission of the Peacebuilding Commission to Guinea-Bissau, 23-25 January 2008, 15.05.2008.

PBC/2/GNB/7, Report of the Mission of the Peacebuilding Commission to Guinea-Bissau, 6-11 April $2008,15.05 .2008$.

PBC/3/GNB/3, Strategic Framework for Peacebuilding in Guinea-Bissau, 31 July 2008, 02.10.2008.

S/1998/1028, Letter dated 3 November 1998 from the Permanent Representative of Nigeria to the United Nations addressed to the President of the Security Council, 03.11.1998.

S/1999/232, Letter dated 26 February 1999 from the Secretary-General addressed to the President of the Security Council, 03.03.1999.

S/1999/1276, Report of the Secretary-General on Developments in Guinea-Bissau and on the Activities of the United Nations Peace-Building Support Office in that Country, 23.12.1999.

S/2000/250, Report of the Secretary-General on Developments in Guinea-Bissau, 24.03.2000.

S/2001/622, Report of the Secretary-General on Developments in Guinea-Bissau and the Activities of the United Nations Peace-Building Support Office in that Country, 22.06.2001.

S/2007/744, Letter dated 11 December 2007 from the President of the Security Council to the Chairperson of the Peacebuilding Commission, 14.12.2007. 
S/RES/1216, Resolution 1216 [on the Process of Peace and Reconciliation in Guinea-Bissau], 21.12.1998.

S/RES/1876, Resolution 1876 [on extension of the mandate of UN Peacebuilding Support Office in Guinea-Bissau (UNOGBIS) and the establishment of the UN Integrated Peacebuilding Office in Guinea-Bissau (UNIOGBIS)], 26.06.2009. 